Click www.researchjournal.co.in/online/subdetail.html to purchase.

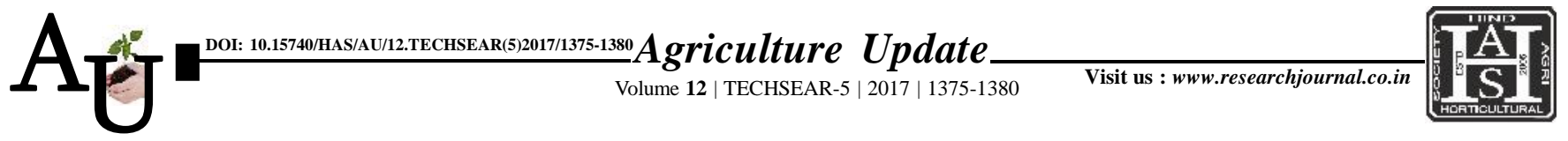

\title{
Rевенсн автісів: Weed dynamics, growth, yield and economics of ajwain (Trachyspermum ammi) influenced by integrated weed management
}

\section{N. NALINI, A. SRINIVAS, T. RAMPRAKASH AND V. PRAVEEN RAO}

Article Chronicle : Received :

15.07.2017;

Accepted :

30.07.2017

KEY WoRDS :

Ajwain, Herbicides, Weed management, Yield, Economics

Author for correspondence :

\section{N. NALINI}

College of Agriculture,

Professor Jayashankar

Telangana State

Agricultural University,

Rajendranagar,

HYDERABAD

(TENALGANA) INDIA

Email : nalinitara@

gmail.com

See end of the article for authors' affiliations
SUMMARY : A Field experiments conducted at Hyderabad (Telangana), to find out the economic feasibility of weed management practices in terms of weed control efficiency and performance of Ajwain (Trachyspermum ammi) indicated that weed-free treatments resulted in higher plant growth, maximum yield attributes and seed yield followed by oxyfluorfen @ $0.12 \mathrm{~kg}^{a} . i \mathrm{ha}^{-1}$ as PE fb quizalfop p-ethyl @ $0.05 \mathrm{~kg} a . i \mathrm{ha}^{-1}$ as PoE at 20 DAS. Maximum net returns (Rs. 67692ha ${ }^{-1}$ ) and highest cost :

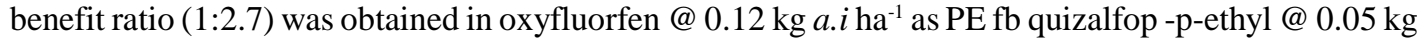
a. $i$ ha $^{-1}$ as PoE at 20 DAS.

How to cite this article : Nalini, N., Srinivas, A., Ramprakash, T. and Rao, V. Praveen (2017). Weed dynamics, growth, yield and economics of ajwain (Trachyspermum ammi) influenced by integrated weed management. Agric. Update, 12(TECHSEAR-5) : 1375-1380; DOI: 10.15740/HAS/AU/12.TECHSEAR(5)2017/1375-1380. 